\title{
Inventory of Estuarine and Lagoonal Ecosystems Subjected to Sand-Mining Activities in Southern Benin (West Africa)
}

\author{
Romaric K. Lalèyè ${ }^{*}$, Hyppolite Agadjihouèdé1,2, Antoine Chikou1, Hamed Adjagbo1, \\ Crépin Assogba1, Djiman Lédéroun ${ }^{1}$, Philippe A. Lalèyè ${ }^{1}$
}

\author{
${ }^{1}$ Laboratory of Hydrobiology and Aquaculture (LHA), Faculty of Agricultural Sciences, University of Abomey-Calavi, Cotonou, \\ Republic of Benin \\ ${ }^{2}$ Unity of Research in Aquaculture, Aquatic Biology and Ecology/Laboratory of Animals and Halieutics Science \\ (URABEA/LaSAH), School of Aquaculture, National University of Agriculture, Kétou, Republic of Benin \\ Email: *kolaromari@yahoo.fr, *laleyeromaric@ymail.com
}

How to cite this paper: Lalèyè, R.K., Agadjihouèdé, H., Chikou, A., Adjagbo, H., Assogba, C., Lédéroun, D. and Lalèyè, P.A. (2019) Inventory of Estuarine and Lagoonal Ecosystems Subjected to Sand-Mining Activities in Southern Benin (West Africa). Journal of Environmental Protection, 10, 473-487.

https://doi.org/10.4236/jep.2019.104027

Received: February 14, 2019

Accepted: April 1, 2019

Published: April 4, 2019

Copyright $\odot 2019$ by author(s) and Scientific Research Publishing Inc. This work is licensed under the Creative Commons Attribution International License (CC BY 4.0).

http://creativecommons.org/licenses/by/4.0/

\section{(c) (i) Open Access}

\begin{abstract}
Sand is a useful resource for the development of any society. As such, the issues related to its extraction are everywhere present in Benin, especially in the southern part of the country. For the purposes of eventually characterizing those issues, the present study is undertaken with a focus on inventorying estuarine and lagoonal ecosystems which are subjected to sand mining in southern Benin. The study area covers both the Eastern Complex and the Western Complex. The Eastern Complex includes the Porto-Novo Lagoon and the Ouémé River delta; while the Western Complex includes the Coastal Lagoon, the Aheme Lake along with its channels, and the Mono Basin. The method used in this study is a systematic inventorying of all known and documented sites as kept on record with relevant state offices in charge of the management of those resources. Then, the data were completed by combing the whole area for direct census observations and field interviews with stakeholders. All inventoried sites have been geo-referenced using a GARMIN GPS and their surface areas have been established. To date, 43 sand-mining sites have been identified, of which 29 are located in the Oueme Delta and in the Porto-Novo Lagoon, 8 are in the Coastal Lagoon, and 6 are in the Aheme Lake and its channels as well as in the Mono River basin. The areas are small in the Oueme Delta, where extraction is mostly manual, but get to be more than 89-ha wide in other places such as the Coastal Lagoon where the process is rather mechanized.
\end{abstract}

\section{Keywords}

Inventory, Sand-Dredging, Aquatic Ecosystems, Southern Benin 


\section{Introduction}

Lagoonal and fluvial sand mining in Benin started as a result of the enforcement of a government decree (since February 24th, 2009) prohibiting the mining of sea/beach sand because such sea/beach sand mining is endangering the coast more and more (government decree no. 2008-615, dated October 22, 2008). The high demand for beach sand for purposes of making concrete for both buildings and city sanitation works has encouraged economic operators who have set up shop with huge machinery, thus giving rise to formal companies approved by the Beninese Agency for the Environment (ABE) [1].

However, this sand-mining activity has the potential to induce modifications in the aquatic habitat resulting in a structural, behavioral, and trophic alteration of the aquatic biodiversity [2] [3] as well as a parallel alteration of the performance of the hydrologic network of the said habitat [4] [5]. Those alterations can be beneficial to the biodiversity (restoration of breeding nests) and can favor reproduction of some species. But they can also give rise to disturbances with negative impacts on aquatic ecosystems. In fact, these alterations can be deleterious to both the habitat and the biodiversity [6] as well as being detrimental to the production and conservation of certain species [7]. On the other hand, sand-dredging benefits the population from the standpoint of income, urbanization, and contribution to the national economy. In spite of all of those outcomes, there is virtually no thorough investigation bearing on the environmental impacts of this activity which is growing in popularity in the aquatic systems of southern Benin. Currently, available studies are characterized by results that are partial [8] and most of these are nothing more than limited-scope studies conducted solely for purposes of getting authorization to conduct the said sand-dredging activity. As a result, the need for an in-depth investigation of the environmental impacts of this activity, which is getting more and more widespread across the river and lagoon systems of southern Benin, has now become an urgent requirement. It is against that backdrop that this study is initiated in order to identify and inventory the various sand-dredging sites located in the estuarine and lagoonal ecosystems of southern Benin, with a view to conducting a future environmental impact investigation of sand mining in this region of Benin.

\section{Materials and Methods}

\subsection{Study Site}

The Western African country of Benin benefits, in fact, from a relatively large network of more or less permanent water bodies. These bodies of water are typically of limited discharge, of limited length, and have irregular flows. They cover the entire country and are split into five watersheds, namely the Mono watershed (100-km long, seasonal flow of 0 to $300 \mathrm{~m}^{3} / \mathrm{s}$ ), the Couffo watershed (190-km long, seasonal flow of 10 to $900 \mathrm{~m}^{3} / \mathrm{s}$ ), the Volta watershed represented by the Pendjari (380-km long, seasonal flow of 0 to $400 \mathrm{~m}^{3} / \mathrm{s}$ ), and the Oueme watershed (510-km long) which turns out to be the most important watershed in 
terms of size [9]. The present work was conducted, on the one hand, on the watersheds of the Eastern Complex of southern Benin which is made up of the Porto-Novo Lagoon, the Nokoue Lake, and the Oueme River delta and, on the other hand, on the watersheds of the Western Complex of southern Benin which is made up of the Coastal Lagoon, the Mono River, and the Aheme Lake along with its channels. These two Complexes were selected because of the high intensity of the sand-mining activity in those regions. Figure 1 shows the geographic map of those two study Complexes.

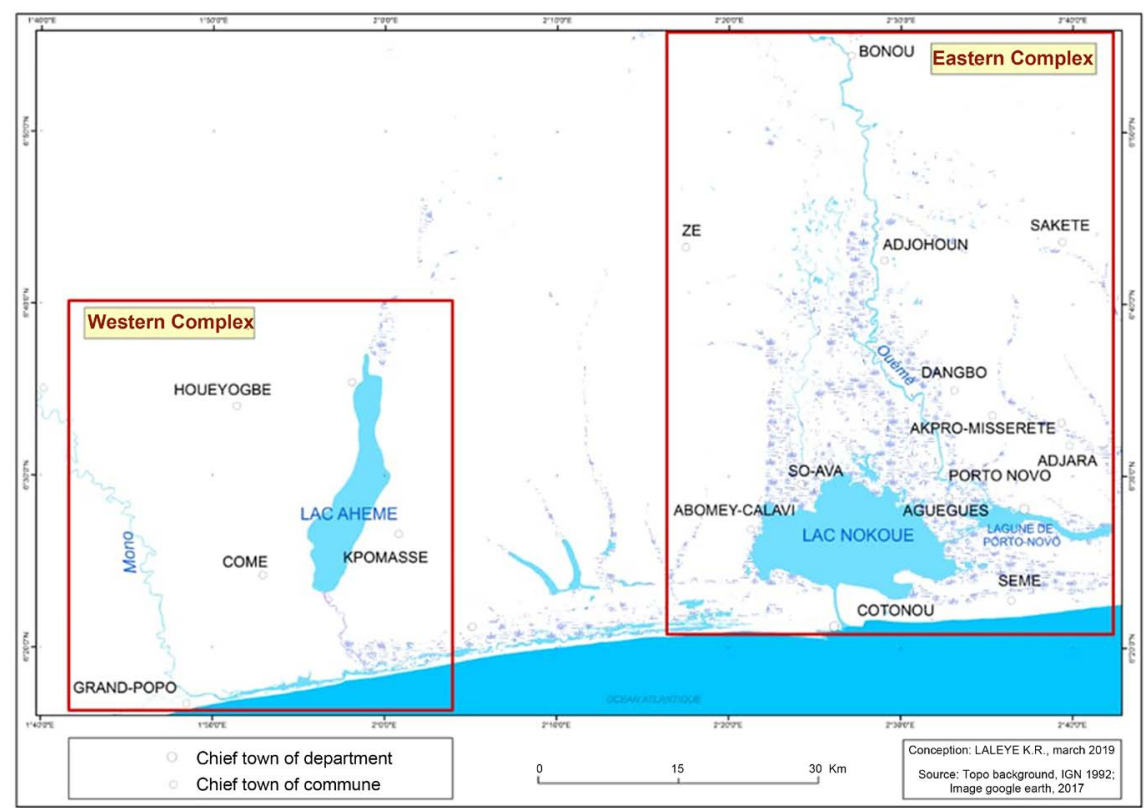

Figure 1. Map of the two study Complexes. Source: Topo background, IGN 1992; Image Google earth, 2017.

\subsection{Inventory of the Sand-Mining Sites}

The sand-dredging sites in the two Complexes have been established through a systematic inventory of all known sites which are on record with local government offices in charge of the management of those resources. Those offices are the National Mines Board, the Benin Agency for the Environment, and the municipal Technical Department of the respective cities. The data were subsequently extended by combing the whole area for direct census observations and on-site interviews with the involved stakeholders.

All of the inventoried sites were geo-referenced using a GARMIN GPS. They were then projected on to a Sheffield file (cartographic map capable of being conceived with points, lines, or polygons) for setting up the geographic distribution of these sites across the two Complexes.

\subsection{Determination of the Areas of the Mining Sites}

All of the dredging sites were tracked using a ground-based GPS device. Once the device is on, the user activates the "Calculate Area" function and follows the 
boundaries of each site of interest. Upon completing a full round and coming back to the starting point, the user presses the "Calculate" button in order to get the area or perimeter of the tracked site. Beyond this operation, the data can also be downloaded onto the computer using the "Basecamp" software. Thus, from these downloaded data and in order to validate the area or perimeter value obtained through GPS, those values are re-calculated one more time using ArcGIS 10.4. With ArcGIS, area or perimeter values are obtained automatically (using the "Calculate Geometry" function) upon creating designated columns for each such parameter.

\subsection{Typology of the Sites}

Typology of the dredging sites was conducted based on the following criteria: area, operating status, the way the sites were acquired, and the sand-dredging method used. For that purpose, a survey was conducted among the involved stakeholders (namely landowners, farmers, transporters, and site workers) using a questionnaire conceived for that goal. In both Complexes, a total of 135 actors including 36 landowners, 29 farmers, 40 transporters, and 30 site workers were surveyed. Upon counting, the data were analyzed using the R software.

\section{Results}

\subsection{Inventoried Sand-Dredging Sites}

A total of forty-three (43) sites were recorded at the two Complexes (the East and West Complexes) which are subjected to various sand-extraction activities (Figure 2). In the Eastern Complex, there are 29 sites on the Oueme delta and Porto-Novo Lagoon. These sites include those of Ahouanzoumè, Awoulotomè,

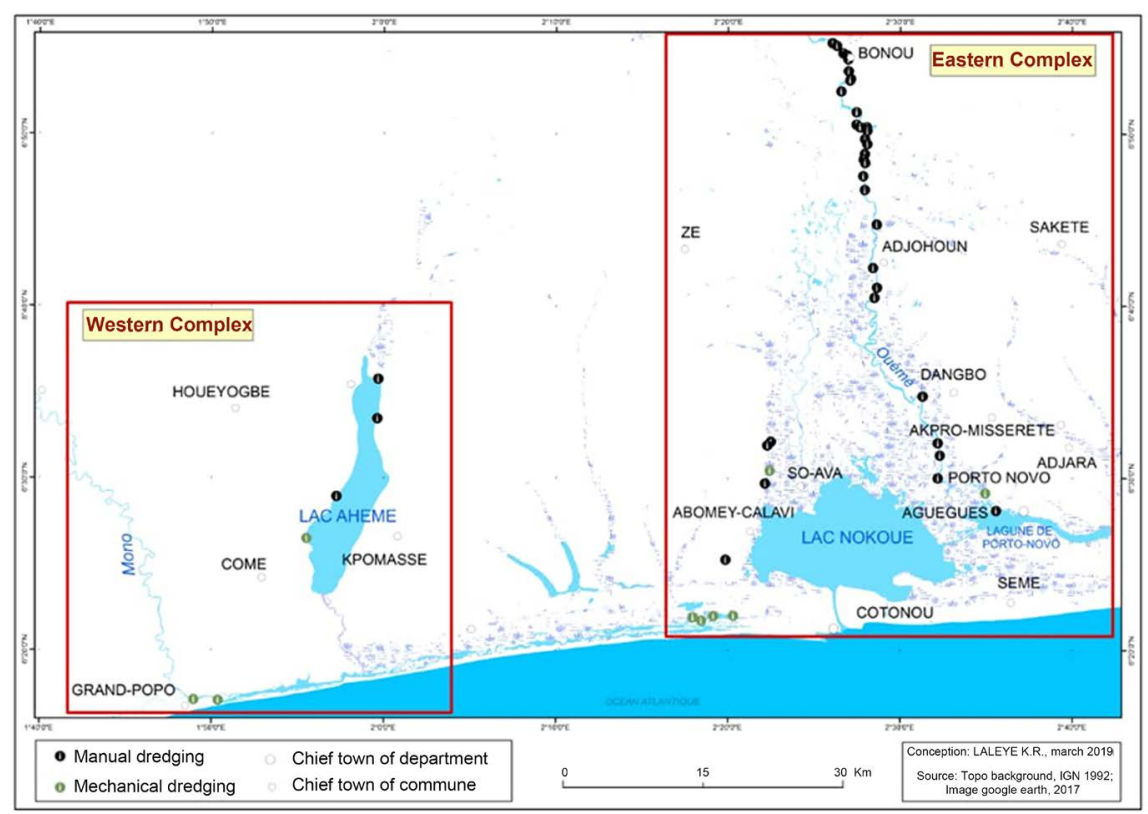

Figure 2. Distribution of sand dredging sites inventoried at the two lagoon complexes in southern Benin. 
Sékodji, Affamè, Dogba, Atchonsa, Ayogo, Agué-kpota, Lokossa, Atchabita, Ouébossou, Dasso, Zoukou-Zomayi, Abèokouta, Ahitonou, Sota, Houvigué, Apkadanou, Agbosso, Agbakon, Abato, Ahouandjinnafon, Codé-Kindji, Allanzoumè, Akpadon, Bembè, Gbodjè, Louho and Djassin.

In the Western Complex, 6 sites were identified on the Ahémé Lake and its channels as well as on the Mono watershed. These sites are those of Dékanmey, Yémè, Ouèdèmè-Pédah, Kpétou, Hèvè, and Houssoukouè. Eight sites were identified on the Coastal Lagoon and are those of Akassato-Center, Glo-Tokpa, Ganganzoumè, Dèkoungbé, Akogbato, Gbodjo, Yèvié, and Wèkèhonou. Of those eight sites, four are not working; that's those of Akassato-center, Glo-Tokpa, Gbodjo, and Wèkèhonou.

Figure 2 shows the distribution of all of the sand-dredging sites as identified at the two Complexes in southern Benin.

\subsection{Areas of the Sand-Mining Sites}

Table 1 and Table 2 present the areas of the various sand-dredging sites as observed at the two Complexes.

Table 1. Area of the sand-dredging sites in the Eastern Complex.

\begin{tabular}{|c|c|c|}
\hline Commune & Site & Area (ha) \\
\hline \multirow[t]{19}{*}{ Bonou } & Ahouanzounmè & 0.24 \\
\hline & Awoulotomè & 0.24 \\
\hline & Lokossa & 0.21 \\
\hline & Ayago & 0.27 \\
\hline & Atchabita & 1.02 \\
\hline & Ouébossou & 0.19 \\
\hline & Sèkodji & 0.24 \\
\hline & Gboa & 0.59 \\
\hline & Affamè & 0.14 \\
\hline & Dogba & 0.2 \\
\hline & Atchonsa & 0.42 \\
\hline & Dasso & 0.03 \\
\hline & Zoukou & 0.19 \\
\hline & Abèokouta & 0.21 \\
\hline & Agué-kpota & 0.19 \\
\hline & Sota & 0.42 \\
\hline & Hounvigué & 3.66 \\
\hline & Apkadanou & 1.3 \\
\hline & Aglossa & 0.53 \\
\hline Adjohoun & Agbakon & 11.09 \\
\hline
\end{tabular}




\begin{tabular}{ccc}
\hline & Dèmè & 1.73 \\
& Ahouandjannanfon & 0.3 \\
Dangbo & Codé-Kindji & 3.93 \\
& Kessounou & 0.72 \\
& Akpa & 6.72 \\
Aguégués & Bembè & 2.3 \\
Porto-Novo & Godjè & 10.96 \\
& Louho & 6.15 \\
& Djassin & 1.56 \\
\hline
\end{tabular}

Table 2. Area of the sand-dredging sites in the Coastal Lagoon and in the Complex made up of the Mono River, Lake Aheme, and the channels of the latter.

\begin{tabular}{cccc}
\hline Zone & Commune & Site & Area (ha) \\
\hline Coastal Lagoon & Abomey-Calavi & Akassato-Centre & 2.80 \\
& & Glo-Tokpa & 1.09 \\
& & Yèvié & 30.01 \\
& Ouidah & Gbodjo & 3.40 \\
& Cotonou & Gekehonou & 4.65 \\
Mono River/Aheme Lake & Dékanmey & Dèkoungbé & 45.81 \\
and connected channels & Bopa & Akogbato & 89.14 \\
& & Dékanmey & 53.39 \\
& & Yémè & 6.15 \\
& & Ouèdèmè-Pédah & 77.18 \\
& & Kpétou & 0.16 \\
& Grand-Popo & Hèvè & 16.7 \\
& & Houssoukouè & 2.4 \\
\hline & & 2.87 \\
\hline
\end{tabular}

Table 1 shows the areas of the various sand-dredging sites at the two Complexes in southern Benin. Indeed, the areas of the sand-dredging sites in the Eastern Complex display great variations, ranging from 0.03 ha to 11.09 ha (Table 1). The smallest areas were observed in the commune of Bonou. In this commune, the areas vary from 0.03 ha to 3.66 ha (mean $=0.54 \pm 0.82, \mathrm{CV}=$ $151 \%)$. In the Adjohoun commune, site areas vary from 0.3 to 11.09 ha (mean = $4.26 \pm 4.80, \mathrm{CV}=112.38 \%)$; in the Dangbo commune, the areas vary from 0.72 ha to 6.72 ha (mean $=3.25 \pm 3.11$ ha, $C V=95.80 \%)$; in the Aguégués commune, the only inventoried and exploited site has a relatively large surface area (10.96 ha); and in the commune of Porto-Novo, the two sites where sand-dredging takes place are 1.56-ha wide and 6.15-ha wide. 
Table 2 shows the area of the sand-dredging sites in the Coastal Lagoon and in the Complex made up of the Mono River, Lake Aheme, and the channels of the latter.

In the Coastal Lagoon, aside from the Glo-Tokpa, Akassato-Center, and Gbodjo sites, everyother sand-dredging site has a large area. The smallest site is 1.09-ha wide (Glo-Tokpa) and the largest is 89.14 -ha (Dèkoungbé) (Table 2). In the complex made up of the Mono River/Lake Aheme and connected channels, the sand-mining sites are also generally wide in area. In fact, the smallest areas are wider than 2 ha, except for Ouèdèmè-Pédah site which is 0.16 -ha wide, while the largest is the Yémè site which is 77.18-ha wide (Table 2).

\subsection{Typology of the Sand-Dredging Sites}

In order to establish the potential groups of sand-dredging sites, Principal Component Analysis (PCA) was applied to the matrix of 43 inventoried sand-dredging sites times 11 variables. The contribution of the first three axes is presented in Table 3. Results are given per variable (Figure 3). The plan under consideration is defined by axes 1 and 2 which accumulate $61.19 \%$ of the observed variability (Table 3). Variables such as site status (ET), number of sand operators (Ne), number of carriers $(\mathrm{Nt})$, number of landowners $(\mathrm{Np})$, number of workers (No), total workforce $(\mathrm{Et})$, area $(\mathrm{Su})$, and type of dredging (Ty) are all located in the positive segment of PCI (the first principal component). However, variables such as number of men (Nh), number of women (Nf), and access mode (Mo) are located in the negative segment of the axis (Figure 3). According to PCII (the second principal component), variables $\mathrm{Nh}, \mathrm{Nf}, \mathrm{Mo}, \mathrm{ET}, \mathrm{Ne}, \mathrm{Nt}, \mathrm{Np}$, and No are

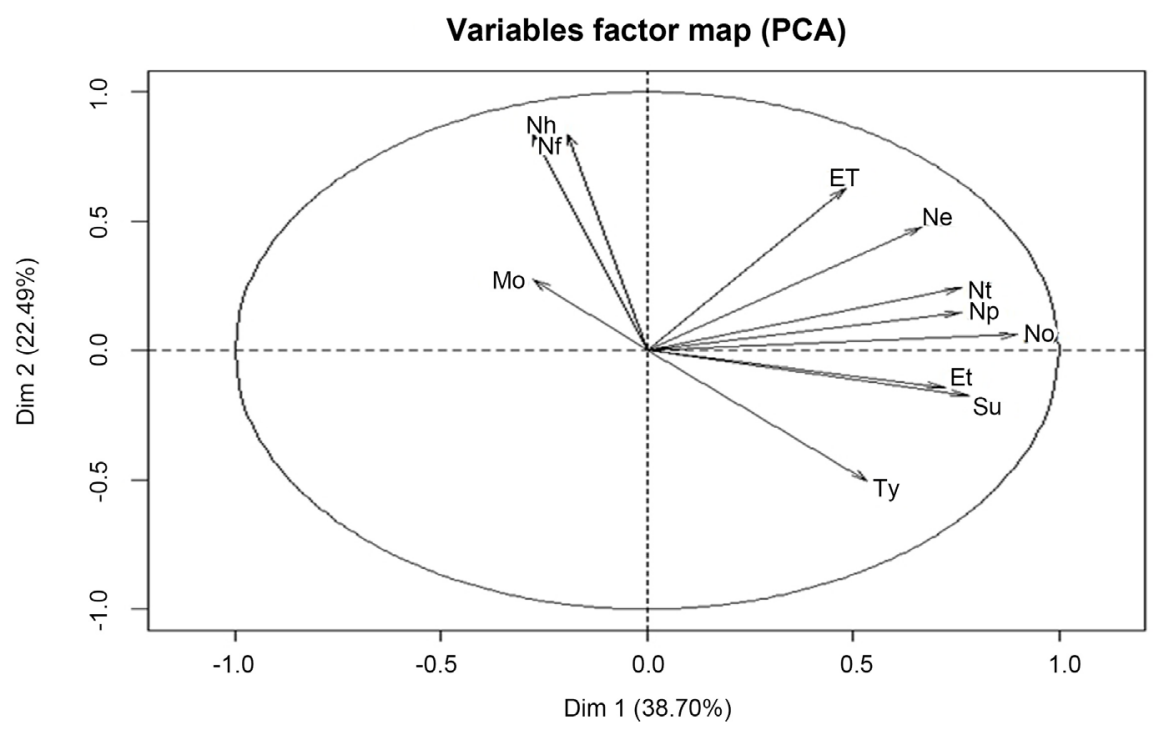

Figure 3. Results of the PCA (principal components analysis) on the variables considered in this study. Legend: site status (ET), number of sand operators $(\mathrm{Ne})$, number of carriers $(\mathrm{Nt})$, number of landowners (Np), number of workers (No), total workforce (Et), area $\mathrm{Su}$, type of dredging (Ty), number of men (Nh), number of women (Nf), access mode (Mo). 
Table 3. Factorial axes contribution of the principal components analysis in discriminating the variables under study.

\begin{tabular}{ccc}
\hline Eigen values & Total & Cumulated \\
\hline Values & variance percentage & variance percentage \\
\hline ET4.25709442 & 38.70085833 & 38.70086 \\
Su2.47415249 & 22.49229537 & 61.19315 \\
Mo1.15213512 & 10.47395566 & 71.66711 \\
Ty0.95275695 & 8.66142684 & 80.32854 \\
Np0.73902875 & 6.71844316 & 87.04698 \\
Nt0.58065920 & 5.27872004 & 92.32570 \\
No0.47005323 & 4.27321117 & 96.59891 \\
Ne0.18311331 & 1.66466644 & 98.26358 \\
Nf0.10929320 & 0.99357454 & 99.25715 \\
Nh0.07503322 & 0.68212018 & 99.93927 \\
Et0.00668011 & 0.06072827 & 100.00000 \\
\hline
\end{tabular}

located in the positive segment of the axis while variables such as $\mathrm{Et}, \mathrm{Su}$, and $\mathrm{Ty}$ are located in the negative part of the axis (Figure 3).

As far as the inventoried dredging sites are concerned, contributions from the first three axes are shown in Table 4. Results are given per site (Figure 4). The plan under consideration is defined by axes 1 and 2 which comprise $61.19 \%$ of the observed variability (Figure 4).

According to PCI, the sites of Sota (Sot), Agbakon (Agk), Djassin (Dja), Ayogo (Ayo), Ouèdèmè-Pédah (Oup), Dékanmey (Dek), Louho (Lou), Yémè (Yem), Akogbato (Ako), Ganganzoumè (Gan), Dèkoungbé (Deo), Yèvié (Yev), Kpétou (Kpe), Hounssoukouè (Hous), and Hèvè (Hev) are located in the positive section of the axis while the other sites are located in the negative section of the said axis (Figure 4). Two groupings can be observed.

According to PCII, the same observation is made (significant spread of the Aka, Gbo, Wek, and Glo sites) and we note that the Oup, Dek, Lou, Yem, Deo, Ako, Hous, Hev, Kpe, Yev, Gan, Aka, Gbo, Wek, and Glo sites are exclusively located in the negative section of the axis. We note, as well, that the Atc, Dog, Apk, Agu, Ahf, Akn, Cod, Ahi, Bem, Aff, Aba, Gbd, Awo, Aho, Sek, Lok, Oue, Das, Zou, Abe, and Housites are mostly located in the positive section of the axis.

Based on these results, the sand-mining sites can be split into three categories or groups, namely Group G1, made up of the Sota (Sot), Agbakon (Agk), Djassin (Dja), Ayogo (Ayo), Ouèdèmè-Pédah (Oup), Dékanmey (Dek), Louho (Lou), Yémè (Yem), Akogbato (Ako), Ganganzoumè (Gan), Dèkoungbé (Deo), Yèvié (Yev), Kpétou (Kpe), Hounssoukouè (Hous), and Hèvè (Hev) sites (Figure 4); Group G2, made up of the Akassato (Aka), Gbodjo (Gbo), Wèkèhonou (Wek), and Glo-Tokpa (Glo) sites which are a cluster of sites from the lagoon complex 
Individuals factor map (PCA)

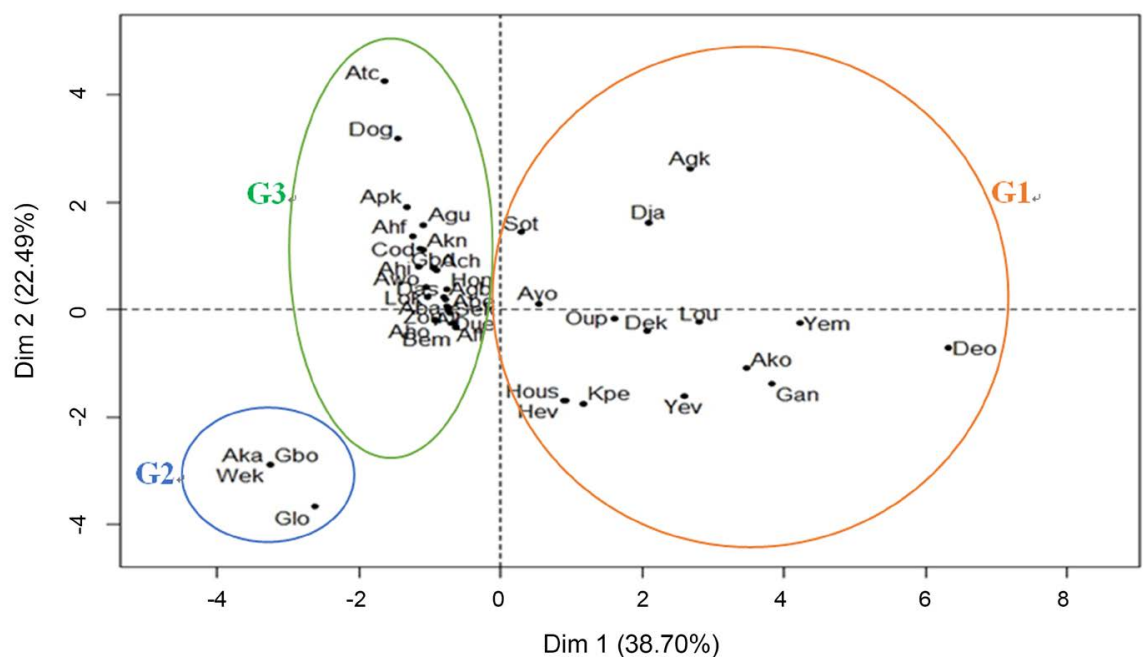

Figure 4. Results of the PCA on the sites inventoried for this study. Legend: Sota (Sot), Agbakon (Agk), Djassin (Dja), Ayogo (Ayo), Ouèdèmè-Pédah (Oup), Dékanmey (Dek), Louho (Lou), Yémè (Yem), Akogbato (Ako), Ganganzoumè (Gan), Dèkoungbé (Deo), Yèvié (Yev), Kpétou (Kpe), Hounssoukouè (Hous), Hèvè (Hev) Akassato (Aka), Gbodjo (Gbo), Wèkèhonou (Wek), Glo-Tokpa (Glo) Atchonsa (Atc), Doga (Dog), Apkadanou (Apk), Agué-kpota (Agu), Ahouandjinnafon (Ahf), Akpadon (Akn), Codé-kindji (Cod), Ahitonou (Ahi), Bembè (Bem), Affamè (Aff), Abaton (Aba), Gbodjè (Gbd), Awoulotomè (Awo), Ahouanzoumè (Aho), Sèkodji (Sek), Lokossa (Lok), Ouébossou (Oue), Dasso (Das), Zoukou-zomayi (Zou), Abèokouta (Abe), Hounvigué (Hon), Agbosso (Agb), Allanzoumè (All), Atchabita (Ach).

Table 4. Factorial axes contribution of the principal components analysis in discriminating the sites under study.

\begin{tabular}{cccc}
\hline & Dimension 1 & Dimension 2 & Dimension 3 \\
\hline Dek & 2.31226795 & $1.547225 \mathrm{e}-01$ & 1.21508258 \\
Yem & 9.78218074 & $5.704761 \mathrm{e}-02$ & 0.81542968 \\
Oup & 1.40804035 & $2.578959 \mathrm{e}-02$ & 0.52916016 \\
Kpe & 0.74529659 & $2.929025 \mathrm{e}+00$ & 0.17810615 \\
Hev & 0.43957529 & $2.672102 \mathrm{e}+00$ & 0.03446939 \\
Hous & 0.44834817 & $2.680359 \mathrm{e}+00$ & 0.03741441 \\
Aka & 5.79766291 & $7.831868 \mathrm{e}+00$ & 2.25654737 \\
Glo & 3.74694108 & $1.267483 \mathrm{e}+01$ & 0.86329412 \\
Gan & 8.00740779 & $1.784468 \mathrm{e}+00$ & 2.36744838 \\
Deo & 21.74255810 & $4.689915 \mathrm{e}-01$ & 5.69186920 \\
Ako & 6.57889514 & $1.113140 \mathrm{e}+00$ & 1.14447030 \\
Gbo & 5.79766291 & $7.831868 \mathrm{e}+00$ & 2.25654737 \\
Yev & 3.67813545 & $2.443905 \mathrm{e}+00$ & 6.14415297 \\
Wek & 5.79766291 & $7.831868 \mathrm{e}+00$ & 2.25654737 \\
Aho & 0.47076867 & $3.422060 \mathrm{e}-02$ & 3.60352964 \\
Awo & 0.61531155 & $1.577001 \mathrm{e}-01$ & 3.48214884 \\
\hline
\end{tabular}




\section{Continued}

\begin{tabular}{|c|c|c|c|}
\hline Sek & 0.29616587 & $4.630619 \mathrm{e}-04$ & 0.04811837 \\
\hline Aff & 0.25494489 & $6.397347 \mathrm{e}-02$ & 0.05040860 \\
\hline Dog & 1.13930916 & $9.467028 \mathrm{e}+00$ & 0.16911228 \\
\hline Atc & 1.45005492 & $1.699391 \mathrm{e}+01$ & 0.11921530 \\
\hline Ayo & 0.16168293 & $1.045593 \mathrm{e}-02$ & 2.73165775 \\
\hline Agu & 0.64873616 & $2.340234 \mathrm{e}+00$ & 0.10447190 \\
\hline Lok & 0.57285862 & $5.129157 \mathrm{e}-02$ & 3.49603530 \\
\hline Ach & 0.44943112 & $5.128710 \mathrm{e}-01$ & 0.08473864 \\
\hline Oue & 0.28947004 & $3.355010 \mathrm{e}-03$ & 0.06024096 \\
\hline Das & 0.34257466 & $4.821835 \mathrm{e}-02$ & 0.06235127 \\
\hline Zou & 0.31592911 & $3.809798 \mathrm{e}-03$ & 0.06574392 \\
\hline Abe & 0.29523884 & $3.007684 \mathrm{e}-04$ & 0.05524584 \\
\hline Ahi & 0.72244508 & $5.846739 \mathrm{e}-01$ & 3.36952869 \\
\hline Sot & 0.04184019 & $1.953980 \mathrm{e}+00$ & 2.76108482 \\
\hline Hon & 0.31489660 & $1.372050 \mathrm{e}-01$ & 0.03702811 \\
\hline Apk & 0.95174075 & $3.401798 \mathrm{e}+00$ & 3.73063418 \\
\hline $\mathrm{Agb}$ & 0.33295514 & $3.164109 \mathrm{e}-02$ & 0.06585755 \\
\hline Agk & 3.89244257 & $6.398513 e+00$ & 14.86490658 \\
\hline Aba & 0.29531469 & $2.100648 \mathrm{e}-03$ & 0.05966819 \\
\hline Ahf & 0.84573643 & $1.759387 \mathrm{e}+00$ & 3.54868566 \\
\hline Cod & 0.70697453 & $1.204701 \mathrm{e}+00$ & 3.73004432 \\
\hline All & 0.30622873 & $3.942261 \mathrm{e}-04$ & 0.06908213 \\
\hline Akn & 0.64278397 & $1.172041 \mathrm{e}+00$ & 3.91030299 \\
\hline Bem & 0.21339789 & $1.090152 \mathrm{e}-01$ & 0.03234897 \\
\hline Gbd & 0.49053820 & $5.562677 \mathrm{e}-01$ & 4.11617574 \\
\hline Lou & 4.27445556 & $5.165565 \mathrm{e}-02$ & 7.00442676 \\
\hline Dja & 2.38313776 & $2.448814 \mathrm{e}+00$ & 12.77666728 \\
\hline
\end{tabular}

Legend: Dimension 1, Dimension 2 and Dimension 3 = Factorial axes contribution of sites under study.

and cannot be lumped together with other inventoried dredging sites (Figure 4); and Group G3, made up of the Atc, Dog, Apk, Agu, Ahf, Akn, Cod, Ahi, Bem, Aff, Aba, Gbd, Awo, Aho, Sek, Lok, Oue, Das, Zou, Abe, and Hou sites that are also a cluster of sites (Figure 4), this time from the Oueme Basin, which slightly overlap with each other. Overall, the analysis of the two main components reveals that there are three sets of sites.

\section{Discussions}

An overall assessment of the benefits that an ecosystem delivers to human society clearly shows that there is a high dependence of the well-being of man on 
those ecosystems [10] [11] and [12]. In Benin, aside from the usual benefits known to continental ecosystems, exploitation of lagoonal and fluvial sand in the aquatic ecosystems of Southern Benin now constitutes a new activity involving multiple stakeholders. The present study, which is the first of its kind in terms of establishing an inventory of the exploited sites, has shown that there are 43 sand-dredging sites in the Eastern and Western Complexes of Southern Benin. That relatively high number of sites is a reflection of an intense activity. In fact, to many of the fishermen in the area, dredging sand for sale is essentially a rescue economic activity which allows them to better handle the challenges they face when it comes to fishing dwindling catch sizes, low fish retail price, etc.). That's the case of the lower Oueme valley where 29 sand mining sites have been inventoried in an area located roughly $50 \mathrm{~km}$ away from the Ouémé River. In the other areas, although the participating sand miners are not just fishermen, the sand-mining activity is still a major one, with a minimum of about 15 inventoried sites, reflecting the level of importance of this activity in there. This state of affairs is due, on the one hand, to the use of sand as an aggregate in the development of infrastructures (housing, roads) and, on the other hand, to the invasion of continental aquatic ecosystems subsequent to the ban on the mining of marine or beach sand. According to [13], sand is a crucial resource for the development of society, and its exploitation in the water bodies of Benin is an income-generating activity for local communities as well as for other stakeholders. In Lake Nokoue, the yearly profit resulting from sand mining is about $\$ 2.44$ million generated by $127.818 \mathrm{~m}^{3}$ of manually-mined sand [13].

The existence of a differentiation between the 11 studied variables was clearly exposed by the various analyses we've made (Principal Component Analysis). The axes group the variables that make it possible to categorize the sites, that is to say the variables that characterize each site. Thus, these axes are formed by the discriminant variables. Each variable generates eigenvalues whose percentage variance expresses the importance (occurrence) of this variable in the formation of the axes with respect to the variables. The cumulative percentage is the sum of the variances generated by the variables studied. Thus, we observe that the total percentage of variance decreases according to the different variables studied while the percentage of cumulative variance increases according to these same variables (Table 3). The variables: sites status (functional and non-functional) (ET) and area of the dredged sites $(\mathrm{Su})$ present the best contributions in the formation of the axes, respectively $38.7 \%$ and $61.19 \%$. In addition to the access mode variable (Mo: 10.47\%), the other variables such as: number of sand operators $(\mathrm{Ne})$, number of landowners $(\mathrm{Np})$, number of workers (No), total workforce (Et), type of dredging (Ty: mechanical and manual), number of men (Nh), number of women (Nf), contributed very little to the formation of the axes (less than $10 \%$ ). The majority of the variables have contributed to this separation. On the other hand, others have turned out to be without influence. The large gap observed in the group consisting of the sites of Akassato, Gbodjo, Glo-Tokpa, and Wèkèhonou is due to the fact that those sited are not currently being ex- 
ploited. On the other hand, the group made up of the sites of Agbakon, Djassin, Sota and Ayogo is so set up probably because of variations in a number of variables such as number of women $(\mathrm{Nf})$, number of men $(\mathrm{Nh})$, number operators $(\mathrm{Ne})$, number of workers, and number of carriers $(\mathrm{Nt})$. The same observation was made with regard to the two other groups consisting of the sites of Ouèdèmè-Pédah, Dékanmey, Yémè, Houssoukouè, Hèvè, Kpétou, Yèvié, Akogbato, Ganganzoumè, Dèkoungbé, on the one hand, and of Atc (Atchonsa), Dog (Doga), Apk(Apkadanou), Agu (Agué-Kpota), Ahf (Ahouandjannanfon), Akn (Akpadon), Cod (Code-Kindji), Ahi (Ahitonou), Bem (Bembè), Aff (Affamè), Aba (Abaton), Gbd (Gbodjè), Awo (Awoulotomè), Aho (Ahouanzounmè), Sek (Sèkodji), Lok (Lokossa), All (Allanzoumè), Oue (Ouébossou), Das (Dasso), Zou (Zoukou zomayi), Abe (Abèokouta), and Hon (Hounvigué), on the other hand. In fact, the same variables have made it possible to discriminate the various inventoried dredging sites. The influence of these variables in the discrimination of the 43 inventoried sites is potentially a reflection of some environmental parameters relative to those water bodies. The small areas of the sand-dredging sites as observed in the lower Ouémé valley are due to the way sand in that region is mined. In fact, in that area, sand-dredging is a fully manual operation whereby miners use canoes, basins, and shovels to get the sand out of the water. The dredged sand is then piled up in the canoes and conveyed to the shore. This activity involves men, women, and sometimes children or teenagers (Figure 5). In both the lagoon and the Mono River areas, the mining process is mainly mechanized; this explains the large areas covered by the dredging sites, particularly in the Coastal Lagoon. Indeed, these sites are operated by companies approved and authorized by the relevant state offices in charge of oversight of those resources in the country. We note that the Dèkoungbé and Ganganzoumè sites are wetlands or marshes bordering the Coastal Lagoon and are used as sand quarries (Figure 6). On the other hand, this activity has given rise to large, standing pools of water which are invaded by aquatic organisms (weeds, fish, crustaceans, molluscs, etc.).

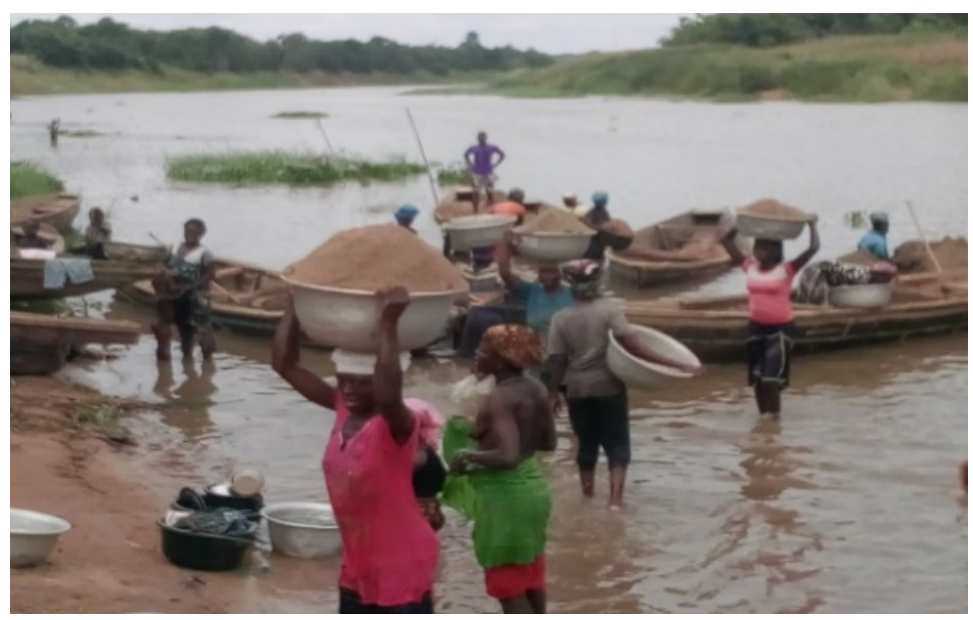

Figure 5. Sand mining in the Ouémé Delta. 


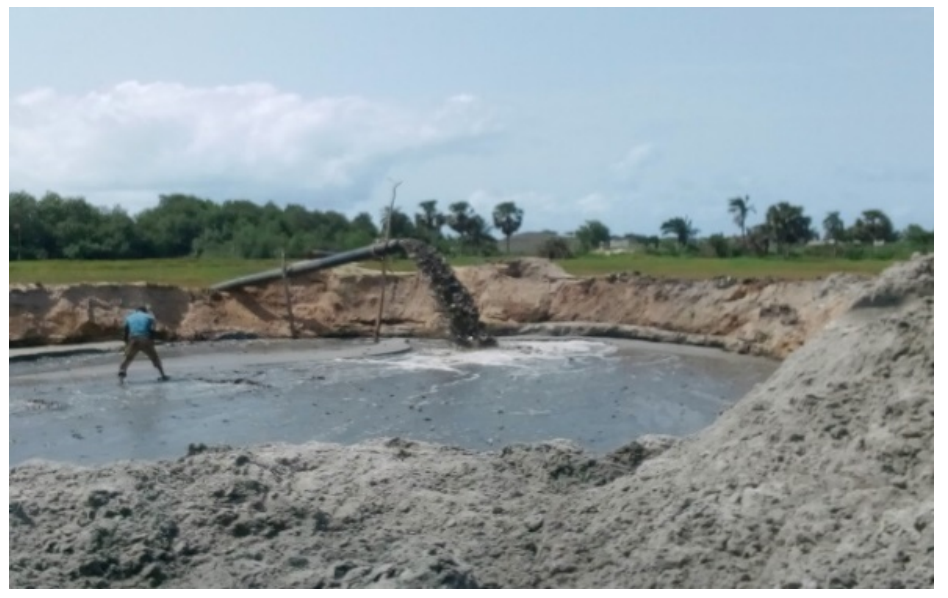

Figure 6. Sand dredging at the Ganganzoumè site.

The results obtained through this work show the importance and originality of this study. Indeed, of all the works that exist around the world, none has been interested in the inventory and distribution of sand extraction sites in continental ecosystems. In overseas countries, sand mining works only for marine dredging [3] [4] [14]. In Benin, the few works that exist are those of [15] which deal with the environmental and socio-economic impact of the exploitation of lagoon sand in Grand-Popo (Benin), [13] who made an economic assessment of manual dredging in Grand-Nokoué and [8] who compared the reproductive parameters of Sarotherodon melanotheron populations in the coastal lagoon and the Togbin dredged water reservoir. This study demonstrates the extent to which sand dredging activity is occurring in continental aquatic ecosystems and the effects of which may be of several orders. Then, one ought to be wondering what the impacts, on these aquatic ecosystems and on the organisms living therein, of this sand-mining activity growing at an alarming rate are?

\section{Conclusion}

Inventorying sand-mining sites in the aquatic ecosystems of southern Benin has led to the identification of over 40 sites where sand mining takes place. This study presents the most comprehensive inventory yet. However, it covers only the southern part of Benin and it would be useful to extend this investigation to the other regions of Benin. On the other hand, of the 43 sites identified and inventoried, the majority applies a manual procedure while the remainder follows a mechanized approach. Given the scale of this activity, it would be interesting to establish what its environmental impacts on the involved aquatic ecosystems are.

\section{Acknowledgements}

We wish to thank, the National Mines Board of Benin, the Benin Agency for the Environment, and the municipal Technical Department of the respective cities for having made available to us the necessary documents for the purposes of this study. We also sincerely thank all the stakeholders involved in sand mining for 
their noticeable openness, spirit of sharing and exchange during our field investigations. Finally, our thanks equally go to all of those who helped us in the field with data collection.

\section{Conflicts of Interest}

The authors declare that there is no conflict of interest regarding the publication of this paper.

\section{References}

[1] CCIB (Chambre de Commerce et d'Industrie du Bénin) (2015) Liste des entreprises d'exploitation de sable au Bénin.

[2] GEODE (2012) Suivis environnementaux des opérations de dragage et d'immersion. Guide méthodologique. Rapport 134 p.

[3] Hakkou, M., Benmohammadi, A., Castelle, B., Bertin, X., Labraimi, M., El-Hassani, A. and Layachi, M. (2015) Perceptives d'optimisation technique de la gouvernance environnementale des activités du dragage du sable marin au Maroc. Bulletin de l'institut Scientifique, Rabat, Section Sciences de la Terre, 2015, No. 37.

[4] Hakkou, M. (2012) Contribution à l'étude de la dynamique morpho sédimentaire du littoral Bouknadel Kenitra. Thèse de doctorat. Université ibn Tofail, Faculté des sciences, Kenitra, Maroc, 266 p.

[5] Duclos, P.A. (2012) Impacts morpho-sédimentaires de l'extraction de granulats marins. Application au bassin oriental de la Manche. Thèse de doctorat de l’Université de Rouen, 272 p.

[6] Newell, R.C., Seiderer, J.L. and Hitchcock, D.R. (1998) The Impact of Dredging Works in Coastal Water: A Review of Sensitivity to Disturbance Recovery of Biological Resources on the Seabed. Revue annuelle d Océanographie et de biologie marine, 36, 127-178.

[7] Frouin, P. (1996) Structure et fonctionnement des écosystèmes benthiques dans les lagons soumis aux perturbations anthropiques: La lagune de Tahiti, Polynésie française. Thèse de doctorat de l'Université française du Pacifique.

[8] Achoh, M.E., Agadjihouede, H., Gangbe, L., Laleye, K.R., Vodougnon, H. and Laleye, P.(2018) Impact of Dredging on the Ichtyofauna of the Lowlands: Comparison of the Reproduction Parameters of Sarotherodon melanotheron Populations (Rüppell, 1852) of Dredged Lowlands and the Coastal Lagoon at Togbin in Southern Benin. International Journal of Fisheries and Aquatic Studies, 6, 2-7.

[9] Chikou, A. (2006) Etude de la démographie et de l'exploitation halieutique de six espèces de poissons-chats (Teleostei, Siluriformes) dans le delta de l'Ouémé au Bénin. Thèse de doctorat de l'Université de Liège, $486 \mathrm{p}$.

[10] MEA (Millennium Ecosystem Assessment) (2005) Ecosystems and Human Wellbeing: A Framework for Assessment. Island Press, Washington DC.

[11] TEEB (The Economics of Ecosystems and Biodiversity) (2011) TEEB Manual for Cities-Ecosystem Services in Urban Management. http://www.teebweb.org/

[12] Watson, R., Albon, S., Aspinall, R., Austen, M., Bardgett, B., Bateman, I., Berry, P., Bird, W., Bradbury, R., Brown, C. and Bulloch, J. (2011) UK National Ecosystem Assessment: Technical Report. United Nations Environment Programme World Conservation Monitoring Centre.

[13] Djihouessi, M.B., Aina, M.P., Kpanou, B-V. and Kpondjo, N. (2017) Measuring the 
Total Economic Value of Traditional Sand Dredging in the Coastal Lagoon Complex of Grand-Nokoué (Benin). Journal of Environmental Protection, 8, 1605-1621. https://doi.org/10.4236/jep.2017.813099

[14] Hakkou, M., Benmohammadi, A., Castelle, B. and Azidane, H. (2016) Suivi des activités d'extraction du sable marin au Maroc XIV ${ }^{\text {ème }}$ Journées Nationales Génie Côtier-Génie Civil Toulon, 29 juin au 1er juillet 2016. http://www.paralia.fr

[15] Kombieni, H.A. (2016) Les impacts environnementaux et socio-économiques de l'exploitation du sable lagunaire dans la commune de Grand-Popo (BENIN). Revue de Géographie de l'Université Ouaga I Pr Joseph KI-ZERBO No. 05, Oct. 2016, Vol. 2. 